\title{
Methodology for the study of metabolic syndrome by heart rate variability and insulin sensitivity
}

\author{
Erika Severeyn*, Sara Wong, Gianfranco Passariello, José Luis Cevallos, Deyanira Almeida
}

\begin{abstract}
This work presents a methodology for studying the Heart Rate Variability (HRV) and Insulin Sensitivity (IS) during the Oral Glucose Tolerance Test (OGTT) in subjects with Metabolic Syndrome (MS). For this, it was designed a clinical protocol that includes the acquisition of ECG signals during OGTT for 15 subjects with MS and 10 subjects for control group. HRV parameters were obtained from electrocardiographic recordings. Significant differences in RR values were found between groups in the 30 minutes stage of the OGTT. In control subjects the RR values were higher compared with subjects with MS. The values of normalized low frequencies between baseline stages and the stage at 30 minutes in subjects with MS showed a significant increase in sympathetic tone during the OGTT, that was not observed in group control. The following methods were implemented for quantification of IS: integral equation, insulin sensitivity index, insulin sensitivity, metabolic, HOMA and QUICKI. We found significantly lower values of IS in the group with MS. It was concluded that there are changes in the HRV and the IS in the subjects with MS, which is a pre-diabetic disease. These findings suggest that HRV and IS can be used for diagnosis of MS and prevention of Diabetes Mellitus.
\end{abstract}

Keywords Diabetes mellitus, Metabolic syndrome, Heart rate variability, Insulin sensitivity, Oral glucose tolerance test.

\section{Metodologia para o estudo da síndrome metabólica partindo da variabilidade da frequência cardíaca assim como da sensibilidade à insulina}

Resumo Este trabalho apresenta uma metodologia para o estudo da Variabilidade da Frequência Cardíaca (VFC) e Sensibilidade à Insulina (SI) durante o Teste de Oral de Tolerância à Glicose (TOTG) em indivíduos com Síndrome Metabólica (SM). Para isso, foi projetado um protocolo clínico que inclui a aquisição de sinais ECG durante o TOTG em 15 pacientes com SM e 10 individuos do grupo controle. Os parâmetros da VFC foram obtidos a partir de registros eletrocardiográficos. Diferenças significativas nos valores de RR foram encontradas entre os grupos na fase de 30 minutos do TOTG. No grupo controle os valores de RR foram maiores em comparação com indivíduos com SM. Os valores normalizados de baixas frequências entre as fases da linha de base e a fase de 30 minutos em pacientes com SM mostraram um aumento significativo no tônus simpático durante o TOTG, não observado no grupo controle. Os seguintes métodos foram implementados para a quantificação de SI: integral, indice de sensibilidade à insulina, sensibilidade à insulina, metabólicos, HOMA e QUICKI. Valores significativamente menores de IS foram encontrados no grupo com MS. Podemos concluir que existem alterações na VFC e SI nos indivíduos com MS, caracterizando uma doença pré-diabética. Estas descobertas sugerem que a VFC e SI podem ser usados para o diagnóstico da SM e prevenção da Diabetes Mellitus.

Palavras-chave Diabetes mellitus, Síndrome metabólica, Variabilidade da frequência cardíaca, Sensibilidade à insulina, Teste oral de tolerância à glicose. 


\section{Introduction}

Diabetes mellitus is a disease characterized by the accumulation of glucose in the blood. This is the result of poor performance of the pancreas to produce insulin. The causes of this disease are still unclear, however, there are pre-diabetic conditions that predispose or prelude the development of the disease. Among these conditions is the Metabolic Syndrome (MS). Therefore, early diagnosis and treatment of MS can prevent the development of diabetes, as well as associated diseases such as hypertension and neuropathy (Zimmet and Alberti, 2005).

Several studies reveal the importance of some parameters, such as physiological signs and symptoms, in the diagnosis of diabetes mellitus. Among these we can highlight the Heart Rate Variability (HRV), which, in the early stages of diabetes, show changes including increased sympathetic tone and decreased parasympathetic tone, which could indicate also cardiovascular disorders (Weissman et al., 2006). It was also reported low values of insulin sensitivity in diabetic and hypertensive subjects (Burattini et al., 2009). The methods to quantify the Insulin Sensitivity (IS) are numerous and there are not consensual borders to discriminate MS subjects from normal subjects.

This work proposes a methodology for the study of HRV and IS during Oral Glucose Tolerance Test (OGTT) in subjects with MS. For this, it was designed a clinical protocol that allowed the construction of a database. This database includes the acquisition of Electrocardiographic (ECG) signals during the OGTT, in order to study HRV. This allowed us to determine possible relationships between blood glucose levels and HRV, as well as the determination of IS in both populations.

\section{Materials and Methods}

\section{Selection of subjects}

Subjects were chosen for this study by the following criteria: male, age between 20 and 44 years old, non-smoker, not on drug treatment, without disabilities and without known cardiovascular diseases. Each subject signed an informed consent form, which explains the conditions of test, importance and usefulness.

For the diagnosis of MS it was used the criteria of National Cholesterol Education Program-Adult Treatment Panel (NCEP ATP III), which consist in the presence of two or more of the following characteristics: abdominal circumference in men greater than $102 \mathrm{~cm}$ and in women greater than $88 \mathrm{~cm}$, blood pressure equal or higher than 130/85 $\mathrm{mmHg}$, triglycerides higher than $150 \mathrm{mg} / \mathrm{dL}$, HDL-cholesterol in men lower than $40 \mathrm{mg} / \mathrm{dL}$ and in women lower than $50 \mathrm{mg} / \mathrm{dL}$, fasting blood glucose equal to or higher than $110 \mathrm{mg} / \mathrm{dL}$.

\section{Clinical protocol}

Table 1 shows the tests, measurements and recordings made during the clinical protocol, which consists of the following steps:

- ECG signal acquisition before the OGTT;

- Extraction of blood sample at baseline, with the subject on fasting;

- Ingestion of 75 grams of liquid glucose; and

- Four blood samples extracted in intervals of 30 minutes and, before each of these samples, a fifteen-minute ECG signal was acquired.

The Cardiosoft ${ }^{\circledR}$ software was used for the acquisition of ECG signals and extraction of the RR and QRS intervals. The ECG recordings were

Table 1. Description of tests and measurements during the clinical protocol.

\begin{tabular}{cl}
\hline \multicolumn{1}{c}{ Tests and measurements } & \multicolumn{1}{c}{ Description } \\
\hline Blood tests & $\begin{array}{l}\text { Includes complete hematology, fasting blood glucose, urea, creatinine, cholesterol, } \\
\text { triglycerides, high density lipids (HDL), low density lipids (LDL), very low density } \\
\text { lipid (VLDL), uric acid and alanine transaminase (ALT). }\end{array}$ \\
\hline Anthropometric variables measurement & Height, weight, waist circumference and Body Mass Index (BMI). \\
\hline Clinical variables measurement & Blood pressure. \\
\hline Oral Glucose Tolerance Test (OGTT) & $\begin{array}{l}\text { It consists of oral intake of 75 grams of liquid glucose, followed by the extraction } \\
\text { of blood samples at intervals of 30 minutes and laboratory measurements of insulin } \\
\text { and glucose for each sample. The test lasts 2 hours and, at the end, two curves are } \\
\text { generated: insulin concentration and glucose concentration (these data are used in } \\
\text { different methods for the quantification of insulin sensitivity). }\end{array}$ \\
\hline ECG recording & $\begin{array}{l}\text { The ECG recordings were performed before each blood sampling of the OGTT, } \\
\text { lasting fifteen minutes each, for a total of five records per subject. }\end{array}$ \\
\hline
\end{tabular}


performed at sampling frequency of $1 \mathrm{kHz}$, resolution of 16 bits and 12-lead records (CardioSoft, 2012).

\section{Heart rate variability}

Measurement of HRV is the oscillation during the interval between consecutive heartbeats. This is an established quantitative method, allowing the assessment of cardiac autonomic activity through the study spectral HRV. Based on HRV values, it can be studied the autonomic nervous system and its fluctuations, and, thereby, cardiovascular disorders and diabetes (Chan et al., 2007).

\section{Analysis of the RR series}

The CardioSoft ${ }^{\circledR}$ program was used for the detection of the QRS complex and construction of the RR series. The RR series for each time interval in the OGTT were validated and resampled at $2 \mathrm{~Hz}$. The Wilcoxon and Kruskal-Wallis tests were used in order to find differences between groups and stages of the OGTT in relation to HRV parameters. In all cases, 'p' values ' $<0.05$ ' were considered significant.

\section{$H R V$ parameters}

From the RR series, SD and RMSSD were calculated in the time domain, and the Low Frequency (LF), High Frequency (HF) and LF/(LF + HF) were calculated in the frequency domain. All calculations and algorithms used were implemented and executed in MATLAB. Table 2 shows the description of the parameters.

The RR series extracted were resampled at $2 \mathrm{~Hz}$ to make them a uniform sampled series. From the RR uniform sampled series, the temporal domain parameters (SD and RMSSD) and the frequency domain parameters (LF, HF, and $\mathrm{LF} /(\mathrm{LF}+\mathrm{HF})$ ) were calculated. Frequency domain parameters were calculated using the autoregressive Burg's algorithm.

\section{Insulin sensitivity}

Insulin sensitivity (IS) is defined as the ability of the cells to react to the presence of insulin (Clausen et al., 1996). The IS can be quantified by existing methods that use data from the OGTT; the methods used in this study for the quantification are: integral equation, insulin sensitivity index, insulin sensitivity, metabolic, $\mathrm{HOMA}_{\mathrm{IR}}, \mathrm{HOMA} \beta_{\text {CELL }}$ and QUICKI. The formulation of these methods is specified in Table 3.

\section{Results}

\section{Database}

The database obtained consisted in 25 subjects, of which 15 correspond to a group with MS and 10 to the control group. Significant differences were found between groups in weight and abdominal circumference. However, no significant differences were found in age and height. The MS group presents obesity (with a Body Mass Index (BMI) above 30), which is located mainly in the abdomen. Table 4 shows the anthropometrics data for the MS and control groups.

\section{Parameters obtained from the study of HRV}

The study was performed on HRV data obtained during the OGTT. The following parameters were obtained from the electrocardiographic recordings: RR, HF, LF, RMSSD, SD and LF/(HF + LF). Those values were recorded for each one of the OGTT stages, for both groups.

Significant differences were found between groups in the values of RR during the 30 minutes stage of the OGTT (control group $966.286 \pm 160.146$ ms versus MS group $843.200 \pm 137.478 \mathrm{~ms}$ ). Subjects with MS showed an increase in sympathetic tone during the OGTT, which was not observed in the control group. Significant

Table 2. HRV parameters in time and frequency domain found in this study (Task Force of the European Society of Cardiology and the North American Society of Pacing and Electrophysiology, 1996).

\begin{tabular}{|c|c|c|c|}
\hline $\begin{array}{l}\text { Frequency domain } \\
\text { parameters }\end{array}$ & Units & Description & Frequency range \\
\hline VLF & $\mathrm{ms}^{2}$ & Very low frequency & $<0.04 \mathrm{~Hz}$ \\
\hline $\mathrm{LF}$ & $\mathrm{ms}^{2}$ & Low frequency & $0.04-0.05 \mathrm{~Hz}$ \\
\hline LF normalized & & $\mathrm{LF} / \mathrm{LF}+\mathrm{HF}$ & \\
\hline $\mathrm{HF}$ & $\mathrm{ms}^{2}$ & Power range of high frequencies & $0.15-0.4 \mathrm{~Hz}$ \\
\hline HF normalized & & $\mathrm{HF} / \mathrm{LF}+\mathrm{HF}$ & \\
\hline Time domain parameters & Units & \multicolumn{2}{|l|}{ Description } \\
\hline SDRR & $\mathrm{ms}$ & \multicolumn{2}{|c|}{ Standard deviation of all RR intervals } \\
\hline RMSSD & $\mathrm{ms}$ & \multicolumn{2}{|c|}{$\begin{array}{c}\text { The root square of the mean of the sum of squared differences } \\
\text { between adjacent RR intervals. }\end{array}$} \\
\hline
\end{tabular}


Table 3. Insulin Sensitivity Quantification Methods (Di Nardo et al., 2006; Fernandez et al., 2003).

\begin{tabular}{|c|c|c|}
\hline Methods & Descri & \multirow[b]{2}{*}{ (1) } \\
\hline \multirow{2}{*}{ Integral equation } & & \\
\hline & \multicolumn{2}{|c|}{ 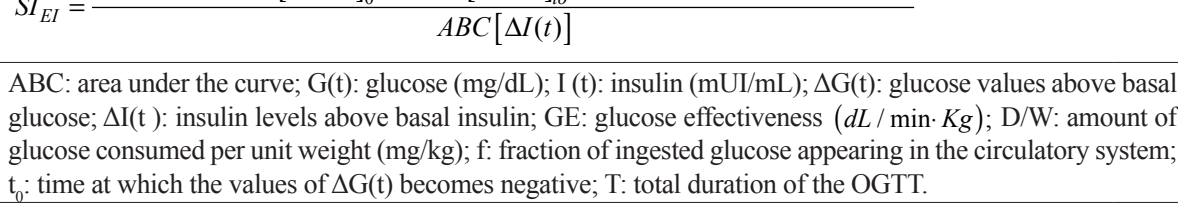 } \\
\hline \multirow{5}{*}{ Insulin sensitivity } & $I S_{\text {OGIS120 }}=\frac{1}{2}\left[B+\sqrt{B^{2}+4 p_{5} p_{6}\left(G_{90} G_{C L A M P}\right) C L_{O G T T}}\right.$ & (2) \\
\hline & $C L_{O G T T}=p_{4} \frac{\frac{p_{1} D_{o}-V\left(G_{120}-G_{90}\right)}{G_{90}}+\frac{p_{3}}{G_{0}}}{I_{120}-I_{0}+p_{2}}$ & (3) \\
\hline & $B=\left(p_{5}\left(G_{90}-G_{C L A M P}\right)+1\right) C L_{O G T T}$ & (4) \\
\hline & $S C=\sqrt{\frac{P T}{3600}}$ & (5) \\
\hline & $\begin{array}{l}\mathrm{G}_{0}, \mathrm{G}_{120}, \mathrm{G}_{90} \text { : glucose concentration in the instants } 0 \\
\text { insulin concentration at the instants } 0 \text { and } 120 \text { minut } \\
\text { unit of body surface area }\left(\mathrm{g} / \mathrm{m}^{2}\right) ; \mathrm{V} \text { : total volume of } \mathrm{d} \\
\left(\mathrm{min}^{-1}\right) ; p_{2}=325(\mu \mathrm{UI} / \mathrm{mL}) ; p_{3}=81.310^{3}\left(\mathrm{mg} \cdot \mathrm{min}^{-1} \cdot \mathrm{n}\right. \\
173\left(\mathrm{~mL} \cdot \mathrm{min}^{-1} \cdot \mathrm{m}^{-2}\right) ; \mathrm{P} \text { : weight }(\mathrm{Kg}) ; \mathrm{T} \text { : subject's heig }\end{array}$ & $\begin{array}{l}0, I_{120}: \\
\text { se per } \\
=650 \\
\text { y } p_{6}=\end{array}$ \\
\hline \multirow{2}{*}{$\begin{array}{l}\text { Insulin sensitivity } \\
\text { index }\end{array}$} & $S I_{I S I}=\frac{10^{4}}{\sqrt{G_{0} I_{0} G_{m} I_{m}}}$ & (6) \\
\hline & \multicolumn{2}{|c|}{$\begin{array}{l}\mathrm{G}_{0} \text { and } \mathrm{G}_{\mathrm{m}} \text { : glucose concentrations at the instant } 0 \text { minutes and mean glucose values at instants } 30,60,90 \\
\text { and } 120 \text { minutes; } \mathrm{I}_{0} \text { and } \mathrm{I}_{\mathrm{m}} \text { : insulin concentrations at the instant } 0 \text { minutes and the average of insulin values } \\
\text { at the instants } 30,60,90 \text { and } 120 \text { minutes. }\end{array}$} \\
\hline \multirow{2}{*}{ Metabolic } & $S I_{I M}=18.8-0.271 B M I-0.0052 I_{120}-0.27 G_{90}$ & (7) \\
\hline & \multicolumn{2}{|c|}{$\begin{array}{l}\text { BMI: expressed as the weight divided by height squared }\left(\mathrm{kg} / \mathrm{m}^{2}\right) ; \mathrm{I}_{120}: \text { insulin concentration at } 120 \text { minutes } \\
\text { of OGTT (pmol/L); } \mathrm{G}_{90} \text { : glucose concentration at } 90 \text { minutes of the OGTT }(\mathrm{mmol} / \mathrm{L}) \text {. }\end{array}$} \\
\hline \multirow{4}{*}{$\begin{array}{l}\text { HOMA } \\
\text { QUICKI }\end{array}$} & $H O M A_{I R}=\frac{G_{0} I_{0}}{405}$ & (8) \\
\hline & $H O M A_{\beta C E L L}=\frac{360 I_{0}}{G_{0}-63}$ & (9) \\
\hline & $Q U I C K I=\frac{1}{\log G_{0}-\log I_{0}}$ & $(10)$ \\
\hline & $\mathrm{G}_{0}$ : Glucose at the instant 0 minutes $(\mathrm{mg} / \mathrm{dL}) ; \mathrm{I}_{\mathrm{b}}$ : Insu & \\
\hline
\end{tabular}

differences were observed for $\mathrm{LF} / \mathrm{LF}+\mathrm{HF}$ in the MS group between the baseline stage $(0.692 \pm 0.093)$ and the 30 minutes stage $(0.757 \pm 0.067)$.

The significant differences between groups and stages found in this study might indicate a very early stage of cardiac dysfunction induced by dysfunctional metabolism of sugars.

\section{Insulin sensitivity obtained from the methods}

Significant differences between groups were found in the following methods: integral equation, insulin sensitivity, index of insulin sensitivity, HOMA $\beta_{\mathrm{CELL}}$, $\mathrm{HOMA}_{\mathrm{IR}}$ and QUICKI. The insulin sensitivity in the control group is higher than in MS group, indicating that for control group the quality of insulin metabolism is better than in MS group. Table 5 shows the values of IS obtained from each method, for both groups.

\section{Discussion}

This study shows the design of a clinical protocol for the study of heart rate variability and insulin sensitivity 
Table 4. Mean anthropometric data and clinical variables for both study groups.

\begin{tabular}{|c|c|c|c|c|}
\hline \multicolumn{2}{|c|}{ Anthropometric data } & Control group & MS group & $p$ values \\
\hline \multicolumn{2}{|c|}{ Age (years) } & $26.90 \pm 4.18$ & $31.40 \pm 6.98$ & NS \\
\hline \multicolumn{2}{|c|}{ Height (m) } & $1.77 \pm 0.09$ & $1.74 \pm 0.07$ & NS \\
\hline \multicolumn{2}{|c|}{ Weight (Kg) } & $73.01 \pm 13.56$ & $104.66 \pm 23.14$ & 0.001 \\
\hline \multicolumn{2}{|c|}{ Abdominal circumference $(\mathrm{cm})$} & $83.51 \pm 10.75$ & $113.63 \pm 19.35$ & 0.001 \\
\hline \multicolumn{2}{|c|}{ Clinical variables measurement } & Control group & MS group & $p$ values \\
\hline \multirow{2}{*}{$\begin{array}{l}\text { Arterial pressure } \\
(\mathrm{mmHg})\end{array}$} & Systolic & $117.60 \pm 9.23$ & $135.13 \pm 7.10$ & 0.001 \\
\hline & Diastolic & $72.40 \pm 7.23$ & $85.67 \pm 10.59$ & 0.006 \\
\hline \multicolumn{2}{|c|}{ Body mass index $\left(\mathrm{Kg} / \mathrm{m}^{2}\right)$} & $23.30 \pm 3.48$ & $34.27 \pm 6.68$ & 0.0003 \\
\hline
\end{tabular}

Table 5. Insulin sensitivity according to the following methods: Integral equation, insulin sensitivity index, insulin sensitivity, metabolic, HOMA and QUICKI.

\begin{tabular}{|c|c|c|c|}
\hline \multirow{2}{*}{ Insulin Sensitivity methods } & Control group & MS group & \multirow{2}{*}{$p$ values } \\
\hline & Mean & Mean & \\
\hline $\begin{array}{c}\text { Integral equation } \\
\left(\mathrm{dL} \mathrm{Kg}^{-1} \mathrm{~min}^{-1}(\mu \mathrm{UI} / \mathrm{mL})\right)\end{array}$ & $6.31 \cdot 10^{-3} \pm 5 \cdot 62 \cdot 10^{-3}$ & $5.93 .10^{-4} \pm 6.21 .10^{-4}$ & 0.001 \\
\hline $\begin{array}{l}\text { Insulin sensitivity } \\
\left(\mathrm{mL} / \mathrm{min}^{2}\right)\end{array}$ & $403.71 \pm 26.44$ & $307.86 \pm 56.31$ & 0.00006 \\
\hline Insulin sensitivity index & $9.57 \pm 4.70$ & $3.48 \pm 2.90$ & 0.001 \\
\hline $\begin{array}{c}\text { Metabolic } \\
(\mathrm{mg} / \mathrm{min} \mathrm{Kg})\end{array}$ & $6.99 \pm 2.66$ & $4.29 \pm 2.83$ & 0.012 \\
\hline HOMA $\beta_{\text {CELL }}$ & $40.86 \pm 24.22$ & $106.00 \pm 59.75$ & 0.006 \\
\hline $\mathrm{HOMA}_{\mathrm{IR}}$ & $0.98 \pm 0.64$ & $3.15 \pm 1.77$ & 0.001 \\
\hline QUICKI & $0.4006 \pm 0.0412$ & $0.3349 \pm 0.0399$ & 0.001 \\
\hline
\end{tabular}

in patients with MS. The database obtained consists of electrocardiographic signals collected during OGTT for a MS group and a control group. Data were analyzed from the point of view of HRV and IS.

The study included 25 subjects - 10 formed the control group and 15 the MS group. The database includes, in addition to traditional variables in the study of subjects with metabolic syndrome (clinical, laboratory and anthropometric variables), the ECG recording during the OGTT. This ECG provides more points of comparison between groups, facilitating the diagnosis of MS. There are alterations in HRV and IS that can appear in a pre-diabetic stage as Metabolic Syndrome. These parameters, HRV and IS, may constitute diagnostic features in the evolution of pre-diabetic patient. This may contribute for easier prevention, diagnosing and managing of important illnesses, such as diabetes and its complications (Navarro and Vargas, 2008).

The ECG acquisition, allowed the calculation of HRV parameters in the time domain (SD and RMSSD) and in the frequency domain (RR, LF, HF and LF/ $(\mathrm{LF}+\mathrm{HF}))$. Significant differences were found in the MS group between stages of OGTT for the values of $\mathrm{LF} /(\mathrm{LF}+\mathrm{HF})$ - the same was not observed in the control group. This indicates an increase in sympathetic tone during the OGTT in the MS group.

In the study of insulin sensitivity, the following methods were used: integral equation, insulin sensitivity index, insulin sensitivity, metabolic, HOMA and QUICKI. Significant differences between groups in all methods were found. The MS group showed lower insulin sensitivity compared with the control group, which represents a metabolic dysfunction reflected in the poor metabolism of glucose.

\section{Conclusion}

Globally, the metabolic syndrome is increasing among the population and should be monitored carefully, since it is a precursor to diabetes and cardiovascular disease. The main contribution of this work is the introduction of a methodology that allows, from a noninvasive test such as the electrocardiogram, to obtain parameters that provide a better understanding of the mechanisms associated with MS. It is expected that the results obtained in this pilot study provide a basis for future research. 


\section{References}

Burattini R, Di Nardo F, Casagrande F, Boemi M, Morosini $P$. Insulin action and secretion in hypertension in absence of metabolic syndrome: model based assessment from oral glucose tolerance test. Metabolism Clinical and Experimental. 2009; 58:80-92. PMid:19059535. http:// dx.doi.org/10.1016/j.metabol.2008.08.010

CardioSoft. Enhanced cardiology research and development of innovative applications -Open-platform ECG system for research. 2012 Jan [cited 2012 Jan 28]. Available from: http://www.cardiosoft.com/index.html

Chan H, Ming-An L, Pei-Kuang C, Chun-Hsien L. Correlates of the shift in heart rate variability with postures and walking by time-frequency analysis. Computer Methods and Programs in Biomedicine. 2007; 86:124-30. PMid:17403552. http:// dx.doi.org/10.1016/j.cmpb.2007.02.003

Clausen JO, Borch-Johnsen K, Ibsen H, Bergman RN, Hougaard P, Winther K, Pedersen O. Insulin sensitivity index, acute insulin response, and glucose effectiveness in a population-based sample of 380 young healthy Caucasians. The Journal of Clinical Investigation. 1996; 98(5):1195-209. PMid:8787683. PMCid:507542. http://dx.doi.org/10.1172/ JCI118903

Di Nardo F, Casagrande F, Boemi M, Fumelli P, Morosini $\mathrm{P}$, Burattini R. Insulin resistance in hypertension quantified by oral glucose tolerance test: comparison of methods. Metabolism Clinical and Experimental. 2006; 55:143-50. PMid:16423619. http://dx.doi.org/10.1016/j. metabol.2005.08.006

Fernandez J. Superficie corporal como indicador de masa muscular en el adulto del sexo masculino. Revista Cubana de Salud Pública. 2003; (29):124-7.

Navarro E, Vargas R. Síndrome metabólico en el suroccidente de barranquilla. Salud Uninorte. 2008; 24(1):40-52.

Task Force of the European Society of Cardiology and the North American Society of Pacing and Electrophysiology. Heart rate variability. Standars of measurement, physiological interpretation, and clinical use. Circulation. 1996; 93:1043-65. http://dx.doi.org/10.1161/01.CIR.93.5.1043

Weissman A, Lowenstein L, Peleg A, Thaler I, Simmer EZ. Power espectral analysis of heart rate variability during the $100 \mathrm{~g}$ oral glucose test in pregnant women. Diabetes Care. 2006; 29:571-4. PMid:16505508. http://dx.doi. org/10.2337/diacare.29.03.06.dc05-2009

Zimmet P, Alberti G. Una nueva definición mundial del síndrome metabólico por la federación internacional de diabetes: fundamento y resultados. Revista Española de Cardiología. 2005; 58(12):1371-6. http://dx.doi.org/10.1016/ S0300-8932(05)74065-3

\footnotetext{
Authors

Erika Severeyn*, Sara Wong, Gianfranco Passariello

Grupo de Bioingeniería y Biofísica Aplicada - GBBA, Universidad Simón Bolívar - USB,

Valle de Sartenejas, Baruta, Caracas, Venezuela

José Luis Cevallos

Laboratorio de Investigaciones Clínicas, Universidad Central de Venezuela - UCV,

Ciudad Universitaria, Caracas, Venezuela

Deyanira Almeida

Servicio de Cardiología del Hospital Universitario de Caracas, Universidad Central de Venezuela - UCV,

Ciudad Universitaria, Caracas, Venezuela
} 